\title{
殺虫剂の水面施用によるウンカ・ヨコバイ類の 防除に関する研究
}

\author{
湖山利篤・鶴町昌市 \\ 農林省農事試験場
}

(1968年 7 月 2 日受領)

\begin{abstract}
Studies on the Control of Leaf- and Planthoppers by Submerged Application with Insecticides. Toshiatu Koyama and Masaichi Tsurumachi (Central Agricultural Experiment Station, Kounosu, Saitama-Pref.) Jap. J. appl. Ent. Zool. 12: 156-163 (1968)

It has been considered that the effect of submerged application with chemical granulars against plant- and leafhoppers is due to the 1 thal action caused by the sucked juice in which translocated insecticides are involved. Therefore, various granular insecticides were tested on their systemic actions. In the application leve! of $3 \mathrm{~kg}$ per $10 \mathrm{a}$, PHC granular (against the small brown planthopper), PHC, MIPG and NAC granulars (against the green leaf hopper) showed a systemic lethal function in the adult insects. This effect was only shown in low mortality and was noticed from the third day after application. Although diazinon and disulfoton have shown a good controling effect in practice, both insecticides showed no systemic lethal function in the application level of $43 \mathrm{~kg}$ per $10 \mathrm{a}$. On the other hand, the results of experiment concerned with the fumigative lethal function in the leaf- and planthoppers showed high fumigative lethal effects in any granular tried in this test, especially diazinon and disulfoton. Supposing from the results of these experiments, the main effect of submerged chemical application in the paddy field is not only due to their killing effect on adult leafhopper which sucked the insecticidecontaining juice of rice plant, but also due to the lethal action caused by the gas evaporated from water surface in the paddy field.
\end{abstract}

緒 言

縞葉枯病，黒すじ萎縮病の媒介昆虫であるヒメトビウ ンカ Laodelphax striatellus FALLÉN はその第 2 回成虫が 周辺の麦畑, 雑草地から本田のイネに移住, 定着する。 移住最盛期は関東地方で平年 6 月中・下旬である。この 最初の移住にひさ続いて，7 月以降も雑草地からの飛び 込みがあるため，上記のイネウイルス病の媒介を防止す るためには，かなり長期にわたり，かつ，完全な防除手 段が必要となる。

ツマグロヨコバイ Nephotettix cincticeps UHLER はイネ 萎縮病の媒介昆虫であるにとどまらず，出穂開花期の異 常多発による直接的な吸汁加害も見過ごせない。8月の 異常多発期にはマラソン郕その他の速効薬剤の散布が慣
行となっているが, 密度低下の期間が短かく, 直ちに復 元する現象がみられるため, 長期間にわたって生息密度 を抑圧する防除の手段が切望されている。

ヒメトビウンカ, ツマグロヨコバイの水田内の密度を 長期間にわたって抑圧するためには，そのほ場に現存す る個体を殺隇するのみでなく，次いでふ化する幼虫およ び周辺からの飛び込み成虫を長期間にわたって直ちに殺 すことが必要である。省力的な, 薬剤の水面施用の利丑 場面では，(1)稲体を吸汁した個体を必然的に死亡せしめ る。つまり, 吸汁食毒作用の強い薬剤の適用がよいの か，また，(2)接触毒性あるいは蒸散ガスによる殺虫性の 強い薬剤が適当であるのかが重要な出発点となろう。

そこで, 初年度の1966年では(1)に関して吸汁殺虫作用 の検定を行なったところ，この作用によって殺虫すると 
考えられていた各種の水面施用剂は意外に作用性がそし く、わずかに P H C 粒剂(商品名，サンサイド粒剤)を選 出することができた。しかし，本剤を適用した1967年の ほ場試験ではその目的を達成することができなかった。 1967年では(2)の，薬剤より蒸散するガスの殺虫性に関し て室内実験を行ない,その結果から判断して, 各種の水 面施用剂によるウンカ類の殺虫はガス作用に負らところ が多いと考兄られた。さらに，1968年のほ場実験の結 果, 野外に沶いて子薬剂から蒸散したガスが防除の主体 であることを確認したので，ここに 1967 年までの経過 を報告して打くことにする。また，1968年以降に行なら ガス効果の確認試験扣よびガス効果を発揮させる別の形 の施用方法とその効果に関しては稿を改ためて報告する 予定である。

\section{吸汁による殺虫効果}

\section{1. 水耕液栽培稲による吸汁毒性の検定}

試験方法 : 第 5 葉抽出の稲苗を, 直径 $2 \mathrm{~cm}$, 長さ $10 \mathrm{~cm}$ のガラス管によって 7 日間水耕液で栽培すれば, 新根が 1 2 cm 伸長する。このとき, 各殺虫剤の希釉液を水耕 液に滴下して所定濃度とすると同時に，活場から採集し たツマグロヨコバイの雌成虫をこのイネに放飤した。24 時間および48時閒後に死虫を数え，これを吸汁によって 死亡したものとみなした。供試虫の放飼は，小型飼育び 几（第1図参照）に穛苗をとおし，綿栓により外気と遮 断し，びん内に成虫 5 頭を入れる方法に上った。

結果：根部から殺虫成分を吸い上げやすい本实鈳方法 では，供試した殺虫剤のいずれもッマグロヨコバイを致 死せしめた。供試薬剤のうち，PHC，MPMC（メオバ 一ル粒剂）は高い食毒作用を示し，水耕液の殺虫剤有効 成分濃度が $15 \mathrm{ppm}$ 以上であれば 24 時間後に $100 \%$ の死虫 率が得られた。NAG (デナネ゚ン粒郕)では150ppmで24 時間後に $90 \%$ ，48時間後には 100\%の死虫率となった。

一方，ダイアジノン粒剂は食毒作用が弱く， 1, 200 ppm の高濃度でも24時間後に $70 \%$ ４8時間後に $90 \%$ の死蟀 を示すにすぎなかった。

以上の実験結果から, 水耕栽培といら条件であれば, ッマグロヨコパイは根から吸収された稲体組織中の殺虫 成分を吸汁することにより死亡するといら事実を明らか にすることができた。

\section{2. ポッ卜栽培稲における吸汁毒性の検定}

試験方法：1/2,000a のポットに栽植されたイ ネの第 5 葉抽出期, ならびに出穂期に, 粈郕の所定量を手まき とし，水深を $2 \sim 3 \mathrm{~cm}$ に維持した。第 5 葉期のイネでは
稲体上半部を, 出穂期では穂部を含めた穂首部を, 第 1 㘠のよらにガラス製飼育びん内に収めて支柱で固定 し

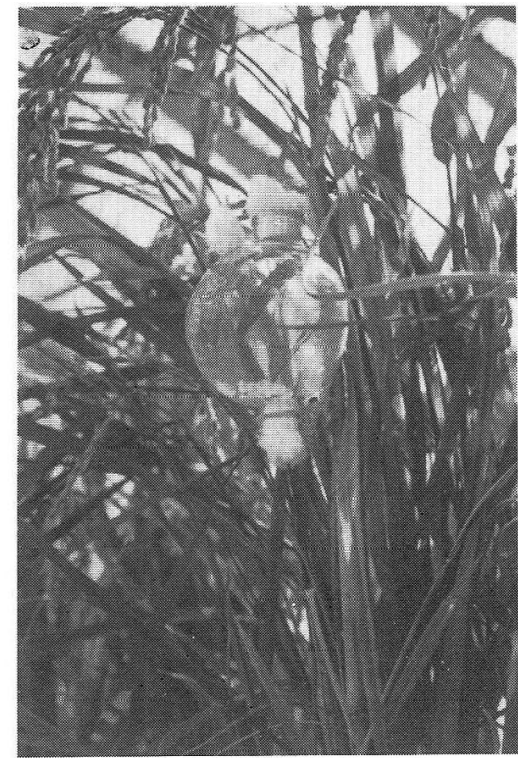

第 1 図ヒとメビウンカの飼育びん。

た。このびん内に10頭の供試虫を所定時間放飼し死虫数 を数えてこれを吸汁による死亡虫と又なした。ヒメトビ ウンカは $25^{\circ} \mathrm{C}$ の定温室で増殖したものを，ッマグロヨ コバイはほ場から採集した成虫を供試した。なお，第 1 図に示した飼育びんは径 $7 \mathrm{~cm}$ の球状部の上下に栓状の 開口部をもち、びん内に稲体をと竌して開口部に綿栓を して外気を遮断するようになっている。びん内の底部に 乾燥凬として $1 \mathrm{~g}$ 程度のシリカゲルを敷き，ガラス内壁 への結露を防いだ。

結果：ヒメトビウンカに刘与る食毒作用一 $1 / 2,000 \mathrm{a}$ ポットによる予備実験では $10 \mathrm{a}$ 当たり $3 \mathrm{~kg}$ （1 ゚゚ット

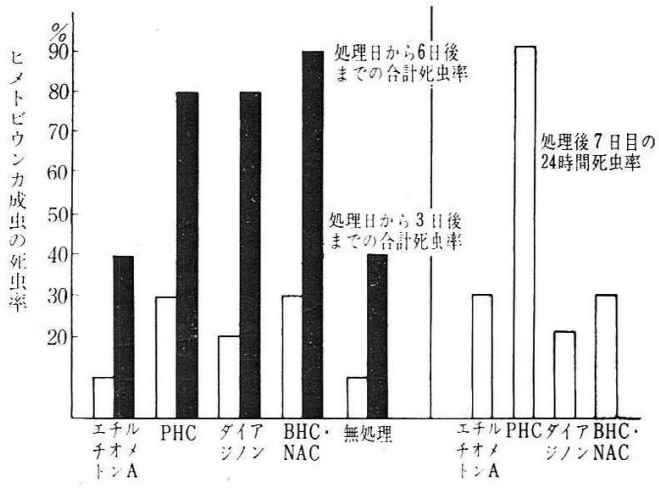

第 2 図 吸汁毒性によるとメトビッンカの死亡率。 
第 1 表 第 5 葉期のポット栽培稲に打けるヒメビウンカの食毒による死虫率 （ 3 ポット，30頭の平均）

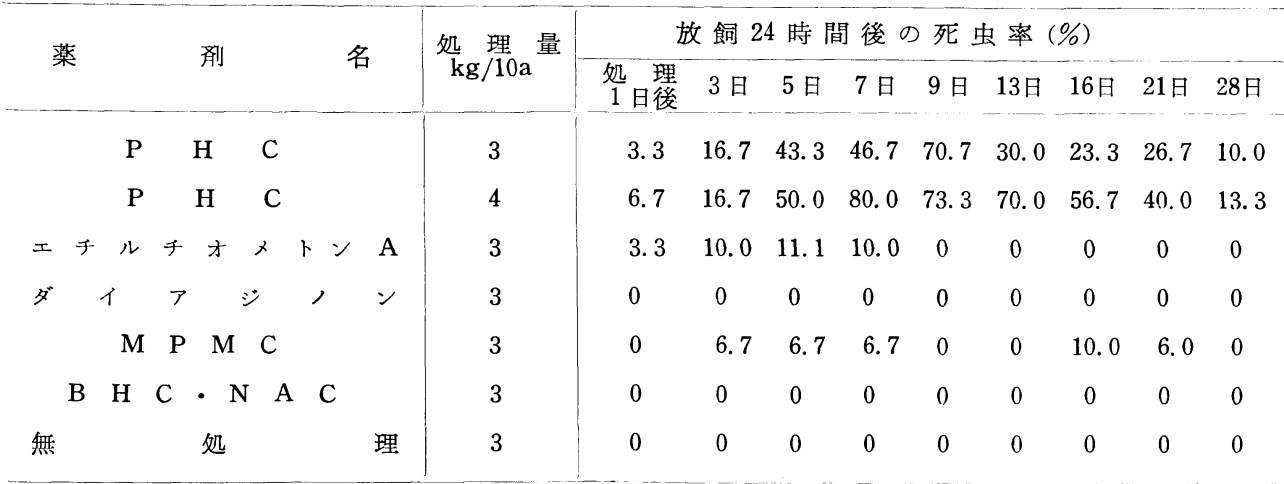

当たり $0.15 \mathrm{~g} ）$ の粒剤施用が食毒の効果を発現せしめる ことを知った。また，水面施用後 3 日間はあまり有効に 食毒作用は働かないが, 施用後 6 日間継続して吸汁させ ると, PHC, ダイアジノン, BHC・NAC（ドルナック 粒剂）の処理は有効のようであった。処理 7 日目に打け る24時間の吸汁では PHC がもっとも高い死虫率を示し たことは第 2 図のとおりである。

そこで, 食毒効果の発現期間, 薬剂の処理量と効果の 関係をみるため, 主として PHG 粒凨について, 第 5 葉 期のイネおよび出穂期のイネを用いて実験したが，前者 は第 1 表，後者は第 3 図にその結果を示した。

第 1 表で明らかなよらに, エチルチオメトンA（ダイ シストン粒剤), ダイアジノン, $\mathrm{MPMC}, \mathrm{BHC} ・ \mathrm{NAC} の$ 水面施用ではヒメトビウンカに 24 時間吸汁させても殺虫 効果はほとんど認められない。それに対して PHCのみ は $3 \sim 4 \mathrm{~kg} / 10 \mathrm{a}$ の施用でヒメトビウンカが吸汁によって

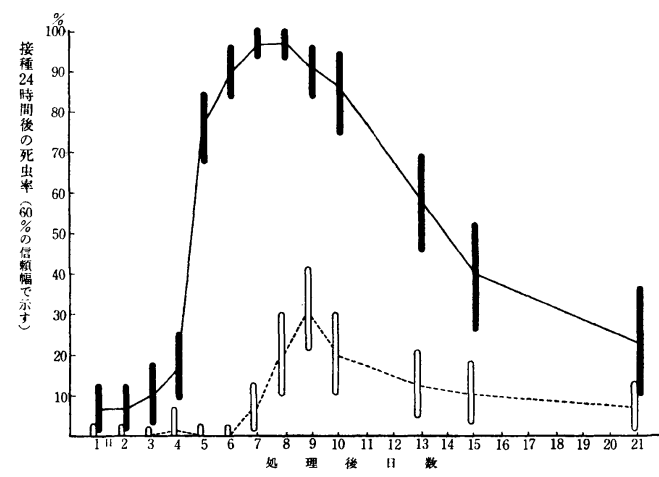

第 3 図 PHG 粒剤の水面施用後に和ける吸汁毒性の 発現消長。実線は $9 \mathrm{~kg} / 10 \mathrm{a}$, 点線は $3 \mathrm{~kg} / 10 \mathrm{a}$ 処理を示す。
明らかに死亡した。30\%以上の死虫率を示す期間は $3 \mathrm{~kg} /$ 10 a の区で処理後 5 日から 13 日， $4 \mathrm{~kg} / 10$ a で 5 日から 21 日であり，とくに後者では7 日目から13日目まで70\%以 上の高い死亡率がえられた。

出穂期における 処理効果は第 3 図のとおりで, PHC $3 \mathrm{~kg} / 10 \mathrm{a}$ ではあまり効果がなく, 処理 9 日目にわずか30 \%の死虫率であったが， $9 \mathrm{~kg} / 10 \mathrm{a}$ 施用では明らかに高い 死虫率がみられた。つまり，処理後 4 日間はほとんど効 果が発現しないけれども5 日目より70\%以上の高い死亡 率を示し, その後ほぼ 1 週間は高い死亡率が継続し, 処 理後15日でもなお $40 \%$ の死亡率を保持した。

また，PHC の吸汁食毒作用に関してはイネのけっ子

第 2 表 ツマダロヨコバイ雌成虫の放飼48時間後における 食毒による死虫率（3ポット，30頭の平均）

\begin{tabular}{|c|c|c|c|c|c|c|c|}
\hline \multirow{2}{*}{ 薬 } & \multirow{2}{*}{ 名 } & \multirow{2}{*}{$\begin{array}{l}\text { 処 理 量 } \\
\mathrm{kg} / 10 \mathrm{a}\end{array}$} & \multicolumn{5}{|c|}{ 処理後の日数 } \\
\hline & & & 2 日 & 4 日 & 6 日 & 8 日 & 10日 \\
\hline \multirow{3}{*}{$\mathrm{P}$} & \multirow{3}{*}{$\mathrm{C}$} & 3 & 0 & 0 & 10 & 40 & 50 \\
\hline & & 6 & 0 & 20 & 20 & 50 & 80 \\
\hline & & 9 & 10 & 20 & 60 & 80 & 90 \\
\hline \multirow{3}{*}{ M } & \multirow{3}{*}{$\mathrm{C}$} & 3 & 3 & 10 & 20 & 23 & 73 \\
\hline & & 6 & 3 & 36 & 30 & 60 & 83 \\
\hline & & 9 & 20 & 50 & 43 & 60 & 93 \\
\hline \multirow{3}{*}{$\mathrm{N}$} & \multirow{3}{*}{$\mathrm{C}$} & 3 & 0 & 3 & 3 & 6 & 3 \\
\hline & & 6 & 3 & 20 & 27 & 27 & 23 \\
\hline & & 9 & 20 & 50 & 30 & 30 & 30 \\
\hline ダイアジ & ノン & 9 & 0 & 10 & 5 & 0 & 0 \\
\hline エチルチオメ & トン $\mathrm{A}$ & 9 & 0 & 0 & 5 & 0 & 0 \\
\hline B $\mathrm{H}$ & $\mathrm{C}$ & 9 & 0 & 0 & 10 & 0 & 0 \\
\hline M $\mathrm{T} M$ & $\mathrm{C}$ & 9 & 0 & 0 & 20 & 10 & 0 \\
\hline
\end{tabular}

注） $1 / 2,000 \mathrm{a}$ ポット栽植の出穂期のイネを供試，無処理の 死虫率は0 $5 \%$ の範井。 
別による効果の差は認められずほぼ同じ程度に発現し， イネの下部, 中部, 穂部といった吸汁部位の差による殺 虫率の差は認められなかった。さらに, 観察によれば吸 汁による殺虫作用が最高に達した期間では, 放飼後 1 2 時間で全数が落下抑転して速効的であり, 雄が雌より も早く落下した。

ツマグロヨコバイに対する殺虫作用——-本種雌成虫に 対する食毒作用の検定結果は第 2 表に示したとおりであ る。それによれば PHC, MIPG (ミプシン粒剂), NAG には食毒作用が認められ，そのらち，前二者に拈いては その作用はかなり強い。しかしダイアジノン，エチルチ オメトンA, BHC, MTMC (ツマサイド粒剤)について は食毒作用を認めることができなかった。

\section{3. ほ場における効果検定}

試験方法：1966年には出穂初めが 8 月20日のマンリョ ウ種の栽植されたほ場において, 穂ぞろい期に該当する 9 月 6 日に各種粒剤の所定量を水面に手まきした。水面 施用による効果の発現経過を知るために, 各区のイネの 株間水面に底面積 $10 \times 15 \mathrm{~cm}$ のポリエチレン製小箱を 1 区につき16個 (合計 $0.24 \mathrm{~m}^{2}$ ) ずつランダムに浮かべ，こ の箱に落下してくるウンカ・ヨコバイ類, クモ類を毎日 調べた。また, 水面施用の10日後に, 捕虫網10回ぶりの
すくい取りによって, 各区に残存する虫数密度を調べた。 結果：1966年秋季のツマグロヨコハイイに対する実験結 果は第 3 表のとおりである。それによると, PHC 粒剤 区では処理後 1 日目にかなりの死虫数がみられた。すな わち, マラソン粉剤による処理 1 日後におけるッマグロ ヨコバイ成・幼虫合計の落下数は調查期間中の全落下数 の $85 \%$ に達するのは当然としても, PHC 粒剤の水面施 用においても $9 \mathrm{~kg} / 10 \mathrm{a}$ 区で50\%，3 kg/10 a 区で35\%程 度に及ぶ落下虫が最初の 1 日間に認められた。この初日 の殺虫機構は，ポット試験による食毒作用の実験結果か ら考えて，稲体を経由する食毒作用ではなく直接接触 かまたは粒剤より発散するガスによるものと推定され よう。また, MPMC 粒㓝は PHC 粒用より落下数は少 なく効果の発現速度は明らかではないが，処理 1 日後の 落下数は $9 \mathrm{~kg} / 10 \mathrm{a}$ 区で全落下数の約半教に及んでい た。また, ツマグロヨコバイの10日後の生き残り数は, マラソン粉剂区より PHG 粒剤区に和ける方が少なかっ た。これは薬剤そのもによる効果の差であり， PHC区 では食毒作用がひき続いて効果を発揮したためと考えて よかろら。

さらに，水面施用によってクモ類がかなり落下して死 亡してしまらことは第 3 表に示したとおりである。

第3 表 ツマグロヨコバイ，クモ類に対する水面施用剤のほ場における効果 (9 月16日登熟期の処理)

\begin{tabular}{|c|c|c|c|c|c|c|c|c|c|c|c|c|c|}
\hline & \multirow{2}{*}{$\begin{array}{l}\text { 施用 } \\
\text { 方法 }\end{array}$} & \multirow{2}{*}{ 薬 㶡 名 } & \multirow{2}{*}{$\begin{array}{c}\text { 処理量 } \\
(\mathrm{kg} / \\
10 \mathrm{a})\end{array}$} & \multicolumn{2}{|c|}{ 落 下 } & \multirow{2}{*}{ 虫 } & \multicolumn{5}{|c|}{ 数 $\left(16\right.$ 箱合計 $\left.0.24 \mathrm{~m}^{2}\right)$} & \multicolumn{2}{|c|}{$\begin{array}{l}\text { 処理10日後の10回 } \\
\text { ぶりすくいとり数 }\end{array}$} \\
\hline & & & & 1 日後 & 2 & & 4 & $5 \cdot 6$ & $7 \cdot 8$ & $9 \cdot 10$ & 合 計 & 盛・納虫 & $\begin{array}{r}\text { 無処理比 } \\
(\%)\end{array}$ \\
\hline \multirow{8}{*}{ 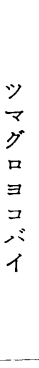 } & 散布 & マラソン粉剂 & 3 & $68(221)$ & $5(15)$ & $2(2)$ & 2 & (7) & (9) & $(2)$ & $77(256)$ & 480 & 61 \\
\hline & 水 & \multirow{3}{*}{ MPMC 粒剤 } & 3 & 0 & $3(67)$ & (20) & (18) & $1(9)$ & (4) & $3(7)$ & $7(125)$ & 334 & 43 \\
\hline & 小 & & 6 & $(25)$ & $4(41)$ & (12) & $2(12)$ & $1(15)$ & (16) & (11) & $7(132)$ & 326 & 42 \\
\hline & 面 & & 9 & $2(69)$ & $6(44)$ & (6) & $2(11)$ & (11) & (8) & (9) & $10(158)$ & 270 & 35 \\
\hline & 施 & \multirow{3}{*}{ PHC 粒 剤 } & 3 & $6(77)$ & $3(62)$ & $2(9)$ & $1(8)$ & $2(24)$ & $2(13)$ & (15) & $16(208)$ & 74 & 15 \\
\hline & & & 6 & $23(216)$ & $5(146)$ & $1(12)$ & $2(10)$ & $5(22)$ & (23) & $3(11)$ & $39(440)$ & 75 & 10 \\
\hline & 用 & & 9 & $24(212)$ & $6(100)$ & $3(19)$ & (19) & $6(20)$ & $2(23)$ & $(10)$ & $41(403)$ & 45 & 3 \\
\hline & \multicolumn{2}{|c|}{ 無 } & 理 & 0 & (2) & 0 & $1(2)$ & 0 & 0 & $(1)$ & $1(5)$ & 785 & 100 \\
\hline \multirow{4}{*}{$\eta$} & 散布 & マラソン粉剤 & 3 & 2 & 1 & 0 & 0 & 4 & 1 & 0 & 8 & & \\
\hline & 水 & \multirow{3}{*}{ MPMC 粒㶡 } & 3 & 0 & 1 & 1 & 2 & 1 & 0 & 0 & 5 & & \\
\hline & & & 6 & 1 & 1 & 3 & 0 & 2 & 1 & 0 & 8 & & \\
\hline & 面 & & 9 & 3 & 3 & 3 & 0 & 2 & 0 & 0 & 11 & & \\
\hline \multirow{2}{*}{$\varepsilon$} & 施 & \multirow{3}{*}{ PHC 粒成 } & 3 & 1 & 1 & 1 & 0 & 0 & 0 & 1 & 4 & & \\
\hline & & & 6 & 3 & 3 & 0 & 3 & 3 & 1 & 0 & 13 & & \\
\hline \multirow[t]{2}{*}{ 類 } & 用 & & 9 & 5 & 3 & 5 & 0 & 1 & 0 & 0 & 14 & & \\
\hline & \multicolumn{2}{|c|}{ 無 } & 理 & 0 & 0 & 0 & 0 & 0 & 0 & 0 & 0 & & \\
\hline
\end{tabular}

注）ッマグロヨコバイ落下虫数の数值は成虫を，括弧内の数值は幼虫を示す。 


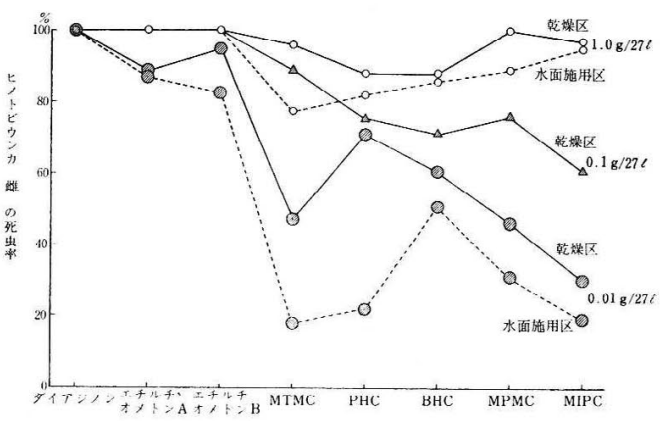

第4目ヒメトビウンカ雃成虫に対する各種殺虫剂 のガス効果 (濃度別処理別の比较)。

\section{蒸散ガスによる殺虫効果}

\section{1. ヒメトビウンカに対する蒸散ガスの殺虫性}

娭定方法：粒剂から蒸散するがスのみによる殺虫力を 知るために，箱内に供試虫と薬剂とを隔離して設置し， 密閉する方法をとった。透明アクリル樹脂製の飼育箱 $(30 \times 30 \times 30 \mathrm{~cm})$ 内の一隅に置いた直径 $9 \mathrm{~cm}$ のシャー レに芽出しイネを入れ，これにヒメトごウンカを放飼 し, これと対角の一隅に所定の粒剂を收容した別のシャ ーレを置いた。この飼育箱は $25^{\circ} \mathrm{C}$ の定温室に24時間経 過させた後開封して, 雌成虫, 雄成虫, 幼虫別飞生・死 虫数を数宎た。供試虫には, 累代飼育虫の羽化 7 日以内 の成出かあるいは老熟幼虫を用い，1 飼育箱当たり成・ 幼虫合計50 - 150 頭を供試した。
薬剂は, $0.001 \mathrm{~g}$ から $5 \mathrm{~g}$ までの範囲の所定量を自動 天科により科量し，シャーレに移したものを乾燥区，こ れに水 $50 \mathrm{ml}$ を加えたものを水面施用区とした。

結果 : 実験結果の一部は第 4 困に示したが，粒剤から 蒸散するガスはヒメトビウンカ成・幼虫を殺す作用をる ち, 殺虫力は薬剤の種類と薬量によって異なった。

第 4 図によればダイアジノン $3 \%$ 粒剂の27 1 0空問 当たり $0.01 \mathrm{~g}$ から蒸散するガスは本種倠成虫の $100 \%$ を 殺す作用を示したが，他の供試薬剂はその量では 100\% の殺虫力は示さなかった。100\%の殺虫力を発揮するこ とのできた薬量はエチルチオメトンAおよびェチルチオ メトン B (エカチンTD)の $5 \%$ 粒剂が $0.1 \mathrm{~g}, \mathrm{MPMC} 6$

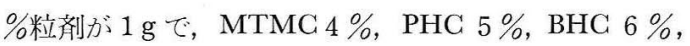
MIPC $4 \%$ の各粒剂は 1 gでも 100\%の殺虫力をらること はできなかった。また供試薬量の減少に伴って殺虫率は 适減するが，その減少幅は薬剤の種類に上って異なり， その愊がきわだって大きいものは MTMC, MPMC, MIPG であった。また，水面施用区の殺虫力をみると， それぞれの薬剂とも乾燥区よりも劣り，とくに MTMC， PHC は 0.01g/27 1 で著しく殺虫力が低下するが, 他剤 は扮扮む䘛燥区と平行して高い殺虫率を示し, 粒剂が 水底に沈積したときでさえも水面よりガ大を発散させた ものと考党られる。

さらに，各楽剤の蒸散ガスによる殺出力を比較するた 㐿様の方法により, 薬量を適当に選定して実験を行 ない, 271 当たりの LD 50, LD 95 を求めた。その絬果

第 4 表 ヒメトビリンカに詨りるガス作用の検定, $\log$ 薬量一死虫率プロビット回帰直線式

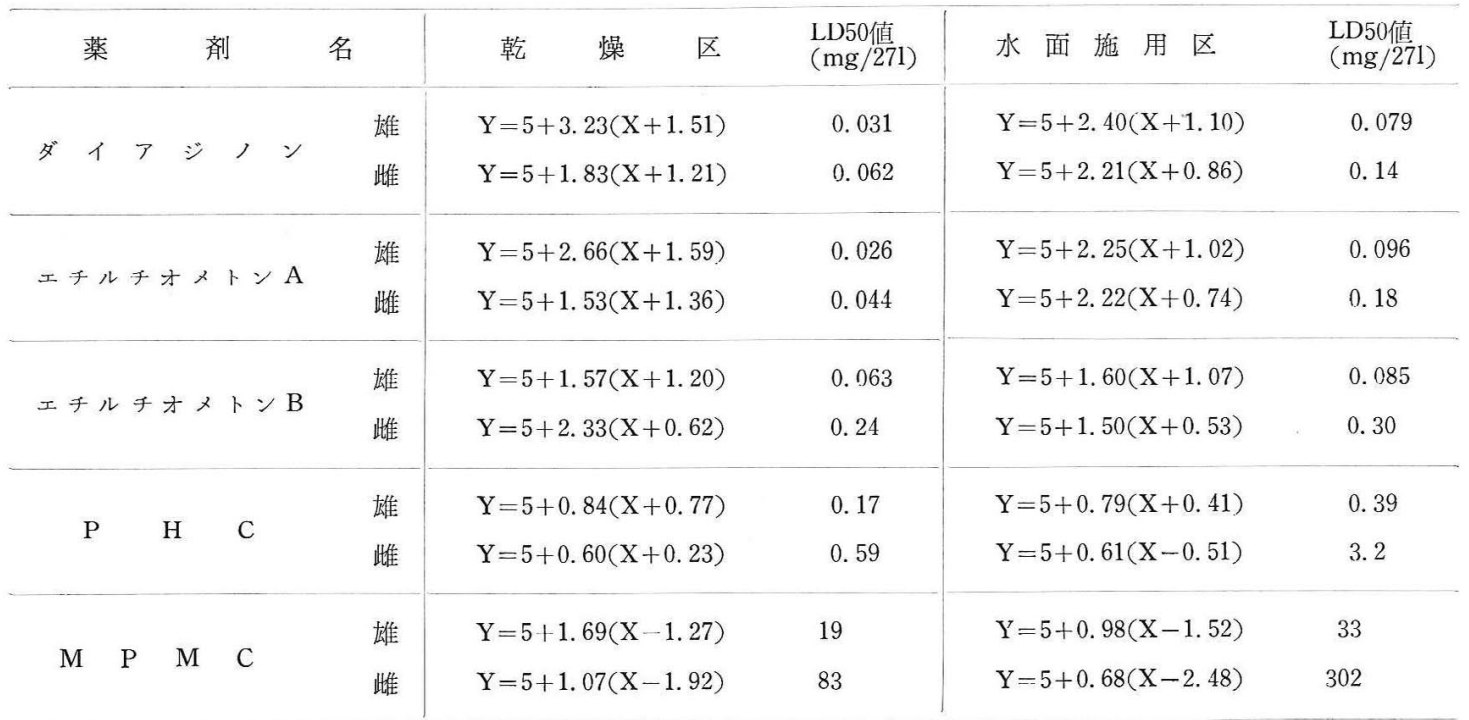

注) $\mathrm{X}$ は密閉空間 271 当たり成分量 $(\mathrm{mg})$ の対数, $\mathrm{Y}$ は $25^{\circ} \mathrm{C}$ で 24 時間経過後の死虫率プロビット。 


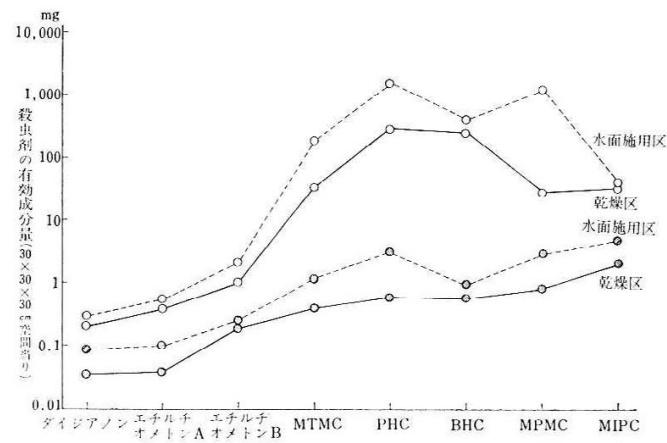

第 5 図ヒメトビウンカに対する蒸散ガスの殺虫濃度。 黒丸は LD 50, 白丸は LD 95 を示り。

は第 4 表および第 5 図のとおりである。まず第 4 表によ れば各薬戍とも前実験と同様水面施用区上りも乾燥区の 方が低いLD 50值を示し，また各薬剂とも殺虫効力は雄 よりも雌に対して低いことがわかる。また第 5 図は成・ 幼虫の合計值に刘する概算值を示したものであるが，乾 燥区でみると，成・幼虫に対するダイアジノン，エチル チオメトンAの LD50 値はその有効成分量で0. 05 mg 以 下であって，ガスによる殺虫汃きわわて強く， LD 95 はダイアジノンで $0.2 \mathrm{mg}$ ，エチルチオイトン $\mathrm{A}$ が 0.4 $\mathrm{mg}$ エエチルチオメトン $\mathrm{B} か ゙ ~ 1.0 \mathrm{mg}$ であり，これら 3 種の薬剂が他剂と比較して格段に強いガス作用を示し た。水面施用区の值も, 乾燥区より若干数值は高くなる けれども，これら 3 種の薬剤は他剂に比べて強いガス效 果が認められた。

\section{2. ツマグロヨコバイに対する蒸散ガスの殺虫性}

検定方法：検定方法はヒメトビウンカの場合と全く同 様である。ただ供試虫は室内での累代飼育のものでな く，12月中旬にほ場より採集した $3 \sim 4$ 令幼虫を $25^{\circ} \mathrm{C}$ の定温室で芽出しイネを与えて飼育し, 羽化を待って用 いた。

結果：271 当たり $0.1 \mathrm{~g}$ の粒剂より蒸散したガスのツ マグロヨコパイ雌成虫に対する殺虫效果は第 6 図に示し たと蛰りである。これによれば蒸散がスによるッマグロ ヨコバイの殺中力は十分に涩められるけれどタ, かなり 低率であって，わずかにダイアジノン $3 \%$ 粒剤とMIPC $4 \%$ 粒剤のみが $60 \%$ の死虫率を示したが，他剤はいずれ も40\%以下であり，エチルチオメトンBと BHC 粒剂と はほとんど殺虫性が認められない程度であった。水面施 用区でもガスによる殺虫性は㴓められるが，乾燥区より もかなり低率となりダイアジノン粒剂が $40 \%$, MIPC粒 剂が30\%，他剂はさらに低下して20\%以下の殺虫率とな った。

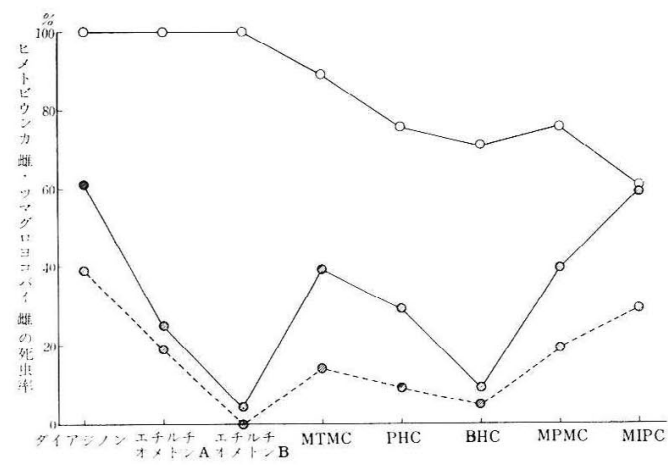

第6図 ソマグロझコバイとヒメトビウンカコの雌成虫 に対するガス效果の比校。白丸はヒメトビウンカ 乾燥区 $9.1 \mathrm{~g} / 271$ ，黒丸実線はツマグロヨコバイ乾 燥区 $0.1 \mathrm{~g} / 271$, 黒丸点線はツマグロヨコパイ水面 施用区 $0.1 \mathrm{~g} / 271$ 。

また，第 6 図に示したように，薬戍より蒸散するガス の本種に刘する殺虫力はヒメトビウンカに対するよりも きわめて低いことと，前者に有効に作用した薬剂が必ら ずしも後者に対しては有効でなく, 両種害虫に共通して 薬剂のガス作用が有効に働らくものとしては, 供試薬刜 中ただダイアジノンのみであった。

さらに，ガスによる殺虫力が独く作用するのは，雄成 虫であることはとメトビウンカの場合と同様であった。

\section{考察}

薬剤を水面施用すれば，イネがその殺虫成分を吸い上 げ,稲体組織に移行するという事実は, 福田・升田(1961) 升田・福田, (1961, 1962), 石井・平野(1962)拉よび平野 (1967)がアイントープを利用した実験によってすでに証 明して打り, 論議の余地はない。そのため, 稲体に移行 した殺虫成分がウンカ・ヨコバイ類に対して殺虫性を発 揮することも当然考兄られるし，実験的にも確認されて いる。著者らの実験によっても, イネを水耕液で栽培し て液中に殺虫片を投下した場合，その稻苗を吸汁したツ マグゥヨコパイは確かに高い死亡率を示した。

ところが，イネをポットに十壤截培して，その水面に 薬剂を投下した実験結果によると，吸汁による死亡率は 二, 三の薬剂をのぞき，きわめて低率であることが確認 された。

ポット栽培という特殊条件のために, 稲体に薬剂の殺 虫成分が十分に移行しないことも推测される。そこで, ほ場での実験と行なった結果, 吸壮殺虫性の強いPHC 粒剂の $6,9,12 \mathrm{~kg} / 10 \mathrm{a}$ 施用の各区とも処理後 $7 \sim 8$ 日李 での放飼24時間死亡率は50\%以下であり，ポット試験の 
第 5 表 ガス作用のみによるとメトビウンカ防除に必要な $10 \mathrm{a}$ 当たり薬剤量（無風, $25^{\circ} \mathrm{C}$ 下）

\begin{tabular}{|c|c|c|c|c|c|c|}
\hline \multirow[b]{2}{*}{ 薬 } & \multirow[b]{2}{*}{ 剤 } & \multirow[b]{2}{*}{ 名 } & & \multirow{2}{*}{$\begin{array}{c}\text { 燥 } \\
10 \mathrm{a} \text { 当たり } \\
\text { 薬㓮量 }(\mathrm{kg})\end{array}$} & 水 面 & 用 \\
\hline & & & $\begin{array}{l}\text { LD95 } \\
\text { 有効成分 }(\mathrm{mg} / 271)\end{array}$ & & $\begin{array}{l}\mathrm{LD} 95 \\
\text { 有効成分 }(\mathrm{mg} / 271)\end{array}$ & $\begin{array}{l}10 \mathrm{a} \text { 当たり } \\
\text { 薬刻量 }(\mathrm{kg})\end{array}$ \\
\hline \multicolumn{2}{|c|}{ ダイアジノン } & $3 \%$ & 0.2 & 0.074 & 0.3 & 0.11 \\
\hline \multicolumn{2}{|c|}{ エチルチオメ } & トンA $5 \%$ & 0.4 & 0.088 & 0.5 & 0.11 \\
\hline \multicolumn{2}{|c|}{ エチルチオメ } & トンB $5 \%$ & 1.0 & 0.2 & 2.0 & 0.44 \\
\hline \multicolumn{2}{|c|}{ MPMC } & $6 \%$ & 29.5 & 5.45 & 1260 & 233.3 \\
\hline \multicolumn{2}{|c|}{ MIPC } & $4 \%$ & 33.1 & 9.17 & 42 & 11.45 \\
\hline \multicolumn{2}{|c|}{ MTMC } & $4 \%$ & 34.7 & 9.62 & 204 & 56.7 \\
\hline \multicolumn{2}{|c|}{ BHC } & $6 \%$ & 251 & 46.3 & 398 & 73.3 \\
\hline \multicolumn{2}{|c|}{$\mathrm{PHC}$} & $5 \%$ & 302 & 67 & 1510 & 336 \\
\hline
\end{tabular}

場合よりもさらに殺虫率は低下した(未発表)。

これらの実験からウンカ・ヨコバイ類の殺虫効果は, 従来一般に考えられているよらに稲体に移行した殺虫成 分によるものかどうか疑わざるを得なくなった。

根部上りもむしろ水浸部の葉鞘から薬剂が浸透移行す ることによって死亡したといら浅野・橋爪（1966）の実 験は蒸散ガスを遮断したことによる効果を誤って判断し たもののよらである。また，橋爪・榎田（1967）やその 他多くの研究者によって行なわれた葉鞘切り取りによる 水面施用剂の効果判定も, 吸汁による殺虫力を検討した ことにはならないであろう。つまり葉鞘表面に, 蒸散ガ スが再結晶して付着していることも考えられるし，また 葉鞘から再放出された有効成分のガスが試験管内に充満 し，それによって死亡する可能性もあるからである。乙 かし, この検定方法に上れば概して高い死亡率を示さな い場合が多い。さらに, 浸透移行に上る効果を発揮した 実験例も多いが，いずれも実用の量をはるかに超えた10 〜20kg/10aの多量施用に限られている。

有機リン剤では, 稲体内で酸化されて代謝物質を生成 する場合が多く, この物質の殺虫性が薬剤の種類によっ て異なることも推定される。一例としてダイアシシノンに ついてみれば, 植物体内に浸透したダイアジノンは酸化 されてダイアン゙クソンとなり,さらに生物活性の高いモ ノチオテップが生成され，また，テップあるいはジチオ テップが生成され, その後いずれは加水分解によって消 失するといわれる。したがって，テップを吸汁したウン カ類は死亡するはずであるが, 福田（私信）は吸汁した ッマグロヨコバイ 1 頭につき 0.004 のダイアジノンを 検出したが，ただし，この場合の死虫率は10\%以下にす ぎなかったという。

稲体に浸透移行した薬剤を吸汁することによって死亡 したと考えられる PHC に関しても，放飼後吸汁しない
で $1 \sim 2$ 時間に落下死亡した観察例から推定して, 飼育 びん内に稲体から放出されたガスの充満によるとも考兄 られ，実際に吸汁によるものかぞらか疑わしい。また， ほ場試験の結果（第 3 表）からみても, 吸汁以外の原因 が殺虫の主体をなしているものと考觉ざるを得ない。

さて, ウンカ・ヨコバイ類の防除に使用されている農 薬は, 対象害虫に対する接触作用, 食毒作用, ガス作用 のいずれかままたはこれらの総合によって殺虫するもの と考えてょい。粒剤の水面施用では, 直接虫体に薬剤が 接触することは少なく，したがって殺虫主体は食毒によ るものと従来考えられていたが，本実験から，蒸散する ガスによるといわざるを得ない。また，ガス作用による 効果はヒメトビウンカに対して強く働き, ッマグロヨコ バイに対しては低下すること, また, 有機リン郕が前者 に強く, カーバメイト系殺虫剂は後者に強く働くことな どの事実は, 従来の防除試験, 虫体散布試験の結果と一 致しておりこの点からも殺虫作用の主因がガスによるこ とを指向しているものと考学る。

岡本ら (1966), 井上 (1968) もまた, ポット試験では ガス作用の:有効なことを明らかにすることはできなかっ たが，広い注場の施用ではガスの充満によって十分に有 効であるとし，ダイアジノン含有の油剤によるほ場での 殺虫性はガス作用によるとしている。

いま, 室内試験の結果から, 無風, 気温 $25^{\circ} \mathrm{C}$ の条 件下で水面より $30 \mathrm{~cm}$ までの閉鎖空間に生息するヒメト ビウンカの成・幼虫に対する蒸散ガスによる防除の 10 $\mathrm{a}$ 当たり所要薬剤量を試算すれば第 5 表のとおりであ る。

これとよれば, 乾燥状態で粒剤を施用するときは, $10 \mathrm{a}$ 当たり $40 \mathrm{~g}$ のダイアジノン粒剤を処理すればガス作用に より全虫数の $95 \%$ を殺すことになり, 慣行施用量の $1 / 40$ で足りる計算になる。水面施用の状態では $110 \mathrm{~g}$ を必要 
とする計算になるが，それでもなお慣行の $1 / 30$ 量にすぎ ない。またエチルチオメトン $\mathrm{A}$ および B も $3 \mathrm{~kg} / 10 \mathrm{a}$ 以 下の施用量で殺虫が可能である。

さらに, このガス作用による殺虫効果は乾燥状態の施 用で高く, 水面施用によって聥減する現象が各薬剤に共 通な現象として認められる。この減少率が異常に高い MPMC, MTMG などは, 水面施用剂としては適当でな く，接触あるいはガス作用を十分に発揮させるよらな別 の形の施用法が考案されるべきであろう。

$$
\text { 摘 要 }
$$

本編では, ツマグロヨコバイとヒメトビウンカに対す る水面施用の防除効果について, その効果の原因を解析 するために行なった実験の結果を報告し, 薬剤の浸透移 行よりも薬剤から蒸散するガス作用が防除効果の主因で あろらと論じた。

1）吸汁毒性のみによるヒメトビウンカ成虫の致死効 果を知る実験では, 各種粒剤のうち, PHC 粒剤が $3 \mathrm{~kg} /$ $10 \mathrm{a}$ で効果を示し, 他の粒剤は全く効果を示さなかっ た。ツマグロヨコバイに対しては, PHC, MIPC, NAC がわずかに効果を示した。

2）これらの薬剤の吸汁毒性による致死作用は施用後 4 日目から発現し，3 日目までは全く効果を示さなかっ た。しかし，ほ場で水面施用を行ない落下する虫数を調 ベてみると，施用後 1 日目にほとんどが落下して死亡 し，吸汁による効果とは考えられなかった。

3）密閉した箱内における粒剂から発散するガスによ る殺虫率をみると，ヒメトビウンカに対してダイアジノ ン，エチルチオメトンはガスによるきわめて高い殺虫作 用をもち, 他の薬剤もかなりのガス殺虫力をもつことが 明らかとなった。ッマグロヨコバイに対してはダイアジ ノン， MIPC はガスによる強い殺虫力を示したが，各
粒剤とも一般的にはヒメトビウンカよりガスの殺虫力は 弱い。また，両種に対して水面施用の状態であってもガ スによる殺虫効果は十分に認められた。

4 ）広く水面施用剂として実用されているダイアジノ ン，エチルチオメトンに吸汁による殺虫性がなく，ガス 殺虫性が高いこと, 吸汁による殺虫性が喼められた PHC もほ場ではガス作用によって殺虫するらしいこと, 現在 施行中のほ場試験によってガス作用による防除効果を認 めたことなどから，ほ場における水面施用による防除効 果の主因は，水底に沈んだ粒剂が，水に溶けるか，別の 経路で大気中にガスを発散させ，これによってウンカ・ ヨコバイ類を殺虫せしめることにあると考察した。

引用 文 献

浅野勝司・橋爪文次 (1966) 水面施用剤に関する試験. 農薬研究 部報告.（昭和40年度）全購連農業技術センター: $217 \sim 223$.

橋爪交次・榎田栄 (1967) ヒメトビウンカ防除剤の効力ランキン グテスト,農薬研究部報告 (昭41年度) 全購連農業技術センタ — : 167 183.

福田秀夫 - 升田武夫 (1961) 殺虫剤の土壌施薬に関する基礎的研 究 第 2 報. 九州病虫研会報. $7: 78 \sim 80$.

平野千里 (1967) 粒剤形態で使用されたダイアジノンの水稲への 浸透. (講演要旨). 応動昆 $11: 34$.

石井像二郎・平野千里(1962)水に溶けた $\gamma$-BHC の水稲茎葉へ の移行について応動昆 $6: 28 \sim 33$.

井上齊 (1968) ヒメトビウンカに対する油剤扣よび粒剈の効果 の解析. 応動昆大会講演.

升田武夫・福田秀雄 (1961) 殺虫凧の土壌施薬に関する基礎的研 究. 第 1 報. 九州病虫研会報 $7: 76 \sim 78$.

升田武夫 福田秀雄 (1962) 殺虫剤の土壤施薬に関する基礎的研 究 第 3 報. 九州病虫研会報 $8: 38 \sim 43$.

岡本大二郎・腰原達雄・安部凱裕 (1966) 殺虫昘の田面施用によ る水稲害虫の防除に関する研究. 中国農試報告 A, No. 13 : $169 \sim 265$. 